\title{
Scandinavia and Israel after the Holocaust
}

\author{
Orna Keren-Carmel
}

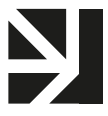

VERTAISARVIOITU

KOLLEGIALT GRANSKAD

PEER-REVIEWED

www.tsv.fi/tunnus

DOI: https://doi.org/10.30752/nj.97348

Aвstract - This article has two distinct yet interrelated aims. Firstly, through an exploration of three examples from Sweden, Norway and Denmark, it seeks to illustrate that an integrated examination of the events of both the Second World War and the Holocaust yields a more accurate, albeit complex, understanding of the period. Secondly, it endeavours to refute the widely accepted assumption that the close relations between Israel and the Scandinavian countries in the early years of Israel's existence were a corollary of the exceptional manner in which these north European states behaved towards their Jewish communities during the war. A historical analysis in fact indicates the opposite, namely that the close ties existing between the countries during the r95os led to the positive, even heroic, depiction of the Scandinavian nations' conduct during the Second World War in Israeli Holocaust commemoration. Together, these twofold aims clearly reflect the implications of early Scandinavian-Israeli relations on the latter's Holocaust memory, and vice versa.

It is widely assumed that the close relations which developed between the Scandinavian countries (Sweden, Denmark and Norway) and the newly founded State of Israel resulted, to a great extent, from the exceptional manner in which these states behaved towards their Jewish communities during the Second World War. The gratitude that the young Israeli nation felt for the rescue actions carried out by the three northern European states was expressed in various ways, including the weaving of close diplomatic ties. Several years after the war, this claim was articulated explicitly in the newspaper Herut, in an article published in September I 957 following the death of the King of Norway, Håkon VII:

The State of Israel and its citizens lower their flags, truly joining the NORWEGIAN people in mourning the death of the nation's king. King Håkon, one of the Righteous among the Nations, passed away in old age - a brave warrior for freedom, justice and fairness. His proud stance in the days of the Hitlerian invasion accorded with his character and that of the nation he led. The State of Israel shares the sorrow of the NORWEGIAN nation, among the just and fairest of the peoples in the world. The State of Israel values the humane attitude of all the SCANDINAVIAN peoples towards the Hebrew nation and its historic homeland. We are grateful for the faithful help extended to us in the international arena by the Scandinavian nations, and by Norway in particular. When the decision was made regarding the right of the Hebrew nation to establish its own country, it was Trygve Lie, a son of the Norwegian people, who in particular stood at our side in those days. Today, the entire world knows what a 
significant role this secretary general played in bringing about the UN's decision in favour of the Hebrew state. However, the Norwegian Trygve Lie did not contribute to returning the Hebrew nation's sovereignty, after two thousand years of subjugation, as an individual. We note with satisfaction the deep understanding that the Scandinavian states reveal towards our problems and our troubles, their support of our creative efforts, and how they have stood alongside us throughout our battle. (Herut I 957: I, all emphasis in original, my translation)

This obituary wove a thread connecting the actions of the Norwegian king during the war, both as an opponent of Nazism and as one of the Righteous among the Nations ${ }^{1}$ (conflating Yad Vashem's distinction), with the aid and support afforded by Norway during the establishment of the State of Israel; linking the decisive contribution made by the first secretary general of the UN, Trygve Lie, with Norway's support of Israel in the many international conflicts that the state faced in the first decade of its existence; and tying the Norwegian people, as one of the Scandinavian nations, with the Hebrew nation in its homeland.

Likewise, the same thread recurred in a welcome speech given by the prime minister, David Ben Gurion, when the Swedish prime minister, Tage Erlander, arrived in Israel in March 1962. Speaking at the airport, Ben Gurion recalled the close relations between

1 Not to confuse with the honorific distinction of Yad Vashem - the Holocaust Martyr's and Heroes' Remembrance Authority in Jerusalem - given to non-Jews who risked their lives during the Holocaust to save Jews from extermination by the Nazis for altruistic reasons. the two states, emphasising that these ties were rooted in the Israeli people's gratitude for the rescue and aid endeavours of the Swedish people in difficult times, as well as for the recommendation of Emil Sandström, the Swedish representative who headed the UN committee for the Land of Israel in I947, in favour of establishing a Jewish state in part of the Land of Israel (Hatsofe r 962: r).

However, a historical analysis of the relations between the State of Israel and the Scandinavian states from the late r 940 until the r 960 o in fact reveals an opposing picture. It appears that the close relations already existing between Israel on the one hand and Sweden, Denmark and Norway on the other led to the positive, even heroic, depiction of the Scandinavian nations' behaviour during the Second World War within Israeli Holocaust commemoration, and not the other way around. In other words, the good relations between Israel and the Scandinavian countries preceded the emergence of a positive commemoration in Israeli Holocaust memory. The three Scandinavian countries acquired a sweeping and homogeneous image as opponents of the Nazis and saviours of the Jews, a fact that subsequently separated the events of the Holocaust in Scandinavia from their wider historical context. Accordingly, the conclusions drawn and the lessons learned regarding these events in Israeli commemorative culture were inaccurate, partial and one-dimensional. ${ }^{2}$ It was only in the I990s, with the publication - mainly by Scandinavian researchers - of comparative and critical studies examining the war events in Scandinavia, that scholars of the war began to integrate research on the Holocaust into

2 For a detailed analysis of the Israeli representation of the rescue of Denmark's Jews see Keren-Carmel 2019. 
their work, enabling the emergence of a more exact, albeit more complex, picture. ${ }^{3}$

After a short introduction, the following sections present three examples, one from each Scandinavian state, illustrating how up-to-date historical research facilitates a deeper understanding of Holocaust events that took place in northern Europe during the Second World War. Among others, each example reflects the different fate the Scandinavian states had during the war: Norway's initial resistance resulting in an occupation regime under Josef Terboven (the Reich's Commissioner), Denmark's surrender leading to a policy of (cooperative) negotiation and finally Sweden's success at keeping neutral. Subsequently, the article analyses the emerging commemoration of Scandinavia in Israeli Holocaust memory, focusing on the imperative roles played by Yad Vashem and the Eichmann trial, in relation to the close ties that began to develop between Israel and the Scandinavian countries in the second half of the r 940s. Examined together, these two distinct yet closely interrelated topics - Israeli-Scandinavian relations and an integrated historical analysis of the Second World War and the Holocaust in Scandinavia - offer a novel perspective on the implications of Israeli foreign policy for the young state's Holocaust memory, and vice versa.

3 There are numerous such studies in the three Scandinavian countries. To mention just a few, in Denmark: Kreth and Mogensen I995; Jensen and Jensen 2003; Kirchhoff 2002; Sode-Madsen I 993. In Sweden: Levine 1996; Koblik I 988. In Norway: Mendelsohn r 969-86; Corell 20io; and various works by Bjarte Bruland. Two interesting analyses of the change in the academic sphere are found in Holmila and Kvist Geverts 20I I, and more recently in Adams and $\mathrm{Heß} 2020$.

\section{Scandinavia after the war}

The year 1945, in which the Second World War ended, is often viewed as signalling the termination of one era and the dawn of another, completely different era; almost all European states underwent extensive changes in their political, economic and cultural structures in the post-war era. Yet the Scandinavian countries in fact exhibited more patterns of continuity than change. One of the most prominent examples of this continuity is the Nordic welfare policy, which began to consolidate at the end of the nineteenth century, when a first wave of welfare lawmaking took place in all three Scandinavian countries. The second such wave occurred during the I93os, following the rise of the Social Democratic parties to power, and over the following two decades the Nordic welfare state was moulded and developed into its current, comprehensive form. The conclusion of the Second World War not only failed to slow this process but even accelerated it: certain spheres of the Nordic welfare state expanded rapidly during the post-war years, in part as a result of the countries' involvement in rehabilitating refugees. Sweden's restrictive immigration policy, for example, ensured there were only about 5 ,ooo refugees at the outbreak of the war in September r 939. By the end of the war this number had risen significantly: in May I945, there were already more than 200,000 refugees in the country. Most originated from neighbouring countries - Norway, Denmark, Finland and the Baltic states - and upon their arrival in Sweden were entitled to the same social benefits as all citizens, funded mainly by the state: they were provided with a place to live, medical care, food and a monthly allowance, and, after a period of acclimatisation, they were granted permission to work (Byström 2013: I 2I). The establishment of a system 
to absorb and care for the refugees, which developed according to trial and error, led to the increased involvement of the Swedish authorities in the lives of individuals. The lessons learned from the treatment of refugees served the government later, in assisting the many immigrants seeking work who arrived in the country in the two decades after the war as well as the state's citizens in need. The new foreign policy that Sweden adopted at the end of the war, that is to say opening its borders without limitations, became a didactic tool for its internal policy, extending the state's responsibility for the individual's living conditions. Thus, it contributed considerably to the institutionalisation of the comprehensive Swedish welfare system (Byström 20I4: 6I5).

With the outbreak of the Cold War, Sweden, Denmark and Norway (and later also Iceland and Finland) looked for ways to boost their involvement in the international arena, seeking to become, together, a geopolitical entity of significance in spite of its rather small size. To do so, they first and foremost sought to depict themselves as 'moral superpowers', that is small countries with a firm moral status, striving fearlessly to protect human rights both within and outside their borders. Their role as mediators in 'NorthSouth' as well as in 'East-West' relations was based on their neutral and anti-colonialist image and established them as forerunners of international socialism. Second, they tried to draw closer to one another in order to become a unified bloc with a similar (although by no means identical) voice in various policy fields. In reality, the attempts to agree on a Nordic defence alliance or a Nordic economic union failed, and the Nordic Council was occupied

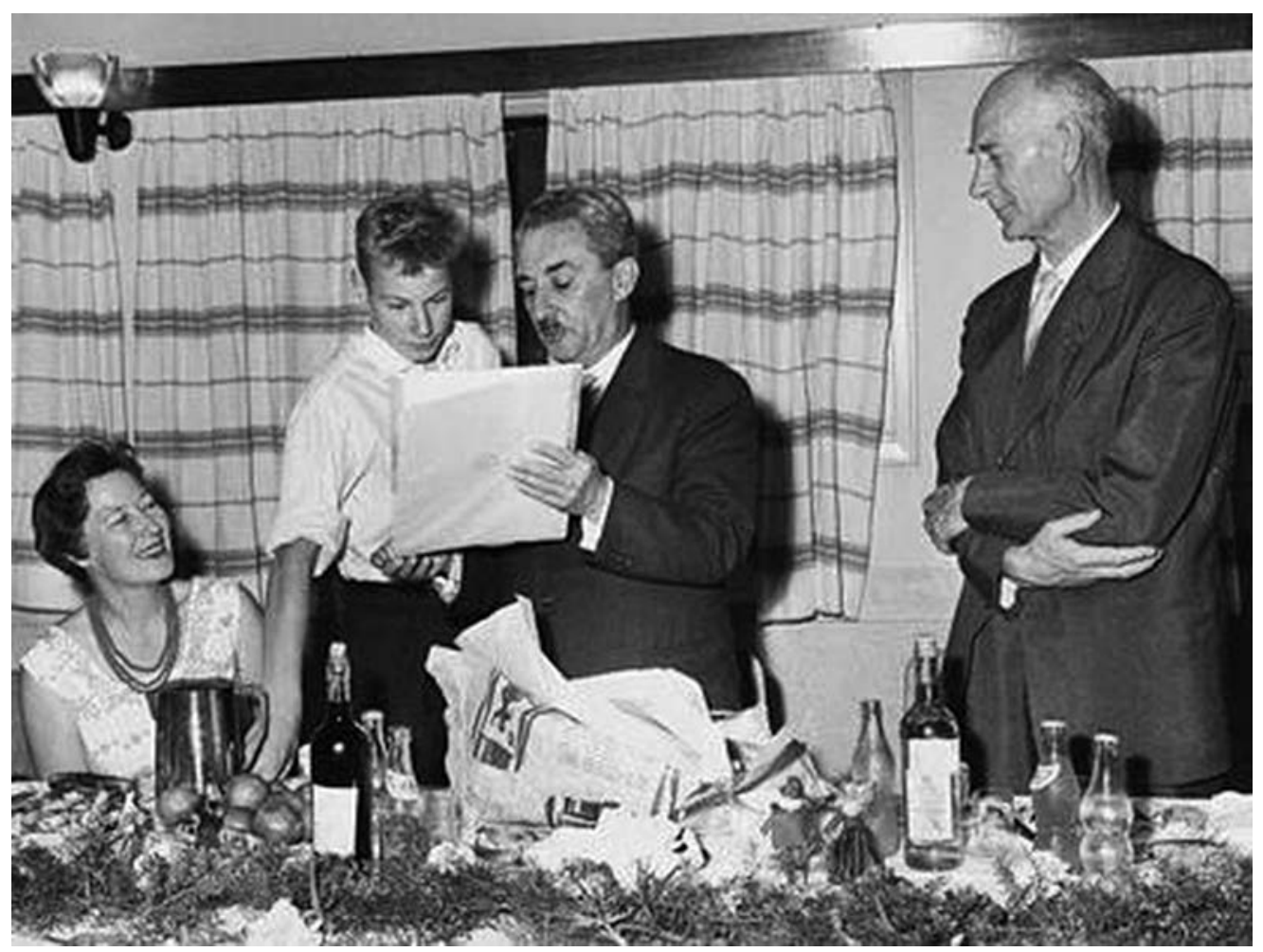

Rune, son of Einar Gerhardsen, Norway's prime minister, receiving reproduction of a painting from Moshe Sharett, in the presence of his parents. Israeli Government Press Office, 16 November 1961. Wikimedia Commons. 
with coordinating their internal policies rather than delineating a common foreign policy. Their main success, however, was close cooperation, which anchored international recognition of them as one bloc.

\section{Israeli-Scandinavian relations}

On 5 January i 930, a social Democratic Party, Mapai (Workers' Party of the Land of Israel) was established in the Yishuv - the Jewish pre-state community in Mandatory Palestine. Upon the establishment of the State of Israel in May I948, this became the ruling party, and its founder, David Ben Gurion, served as the country's first prime minister. Similarly to the Scandinavian Social Democratic parties, Mapai policymakers faced the challenge of absorbing the stream of immigrants arriving in the country following the Second World War, particularly after I 948.

Indications of the close relations that developed between the four states from the late r 940s include the Scandinavian countries' endorsement of the partition plan and their later recognition, de facto and de jure, of Israel; their support for Israel's security policy in votes in the UN; the sale of heavy water (from Norway) to Israel for the purpose of establishing a nuclear reactor; the defence of Israel's interests during the Sinai Campaign (Operation Kadesh); and the active opposition to the Egyptian closure of the Suez Canal to Israeli vessels and/or merchandise. Yet above all, the cooperation between them was especially prominent among the professional echelons of the four countries. The Swedish, Danish and Norwegian trade unions conducted tours of Israel and ran educational and professional training programmes in Israel, while Israeli workers travelled to the Scandinavian countries to learn from their veteran unions. Israel shared its expertise in irrigation, chicken coops and granting aid to developing countries (in this last domain, Israel began its activities a few years before the Scandinavian countries), while Sweden, Norway and Denmark imparted their experience in managing professional bodies such as cooperatives and trade unions. The flow of theoretical and practical knowledge between the four countries largely concerned social topics and welfare policies. This led to close relations, grounded in a shared socialist vision, during the I 950 , making the nations faithful allies in the international arena. ${ }^{4}$

\section{The Holocaust in Scandinavia - an Israeli perspective}

Already during the course of the Second World War, and particularly in the post-war era, the Scandinavian countries acquired a positive image among members of the Yishuv, who were aware of the actions they took on behalf of the Jews dwelling within their borders during the war. ${ }^{5}$ Even before the establishment of the State of Israel, Mordechai Shenhavi, one of the founders of Yad Vashem, was engaged in consolidating a list of names for the first book of the Righteous among the Nations, whose actions were to be commemorated by entering their names into a special book (this plan, however, was never realised) (Kabalek 20II: I48). As such, Shenhavi suggested in 1947 that King Christian X of Denmark, who opposed the Nazi occupation and contributed to

4 For a comprehensive overview of these constructive relations see Henriksen Waage 2000 , in which the author also discusses the relations of Israel with Sweden and Denmark.

5 However, the reaction of the Jewish population of Palestine to the restricted refugee policy towards Jews, which was common in the Scandinavian countries during the I930s, still needs to be researched. 
the exceptional rescue of Denmark's Jews in October 1943, should be declared the first of the Righteous among the Nations. ${ }^{6}$ Independently of Yad Vashem's efforts, on 7 October 1953, the king of Denmark was awarded a special honour during a ceremony held to mark the tenth anniversary of the Danish rescue operation. This official ceremony, attended, among others, by the minister of education and culture, Ben Zion Dinur, the head of the Zionist Histadrut (Workers' Union), Berl Locker, the health minister, Yosef Serlin, and President Yitzhak Ben-Zvi was held in Dir Amar, just outside Jerusalem. During the ceremony, the Eitanim hospital for tuberculosis patients was renamed 'King Christian X Hospital' in honour of the Danish king.

Amidst the events of the war and the Holocaust in Norway, the Israeli public commemorated in particular the activities of the Norwegian underground in opposing Nazi occupation and the help that some of its members afforded to Norwegian Jews fleeing to neutral Sweden. The fact, for example, that the Norwegian police were responsible for both acts of expulsion of Norwegian Jewry in the autumn of 1942 never really entered public and academic debate in Israel. Sweden too, together with Denmark and Norway, received widespread recognition for its rescue actions, mainly the efforts of Raoul Wallenberg and Folke Bernadotte, and for the country's extensive involvement in the rehabilitation of Jewish refugees following the war. However, while Wallenberg was the thirty-first person to be honoured as a Righteous among the Nations by Yad Vashem, Bernadotte was not awarded this title, among other reasons because of the

6 Mordechai Shenhavi to Benjamin Slor, I 7 June r 947, Yad Vashem Archives. intense dispute that erupted regarding his willingness to help Jewish prisoners during the 'White Buses' operation,7 which he headed. The planting of 'Bernadotte Forest' in Jerusalem in January 1952 , rather than a recognition of his contribution to saving Jews during the Holocaust, was an attempt to compensate for the State of Israel's failure to put on trial the members of the Lehi (Stern Gang) ${ }^{8}$ who assassinated him on 17 September 1948, and thus soften the angry Swedish response to this failure. But then again, did this commemorative culture of the Scandinavian conduct during the war adequately represent the actual events that took place there between I 939 and I945? The following three examples, from Norway, Sweden and Denmark, may yield a different answer.

\section{Norway: the Nordic race vs. the Semitic race}

The widespread links between the peoples of Scandinavia and Germany, with mutual influences evident in a range of fields, including academic scholarship, science, art, music and more, date back to the Middle Ages. At the beginning of the twentieth century, a wide range of Nordic movements, which sought to strengthen the relations between the populations of Germany and Scandinavia by promoting the concept of a 'Nordic idea', became popular in Germany. This concept included several facets: geographic (the northern Europe

7 This operation was undertaken by the Danish government and the Swedish Red Cross in April-May I 945 to rescue concentration camp prisoners and transport them to neutral Sweden.

8 Lehi, also known as the Stern Gang, was a Zionist terrorist organisation founded in August 1940 in Palestine by Avraham Stern. 
setting), cultural (the prominent character of work ethic), historical (these peoples were descended from the fearless Viking warriors) and visual (the peoples embodied the ideal of human beauty while the natural landscape was the quintessence of wild nature).

It was, however, the combination of the racial component with the 'Nordic idea', mainly by German theoreticians such as Hans F. K. Günther and Walther Darré, that from the I920s imbued the relations between the Germans and the Scandinavians with a new dimension, one with wide-ranging ramifications. In their eyes, the 'Nordic race' was pure and superior, having rarely blended with other races during the course of history. In the coming years, in accordance with National Socialist racial theory, an elevated status was ascribed to the 'Nordic race', even higher than the 'Aryan race' to which the Germans themselves belonged. Alfred Rosenberg, one of the central ideologists of the Nazi Party, went even further. In his book Der Mythus des 20. Jabrhunderts ('The myth of the twentieth century'), Rosenberg attributed an important role to the populations of Sweden, Denmark, Norway and Finland within the new European order that would emerge after the war, namely defending the Third Reich, and in so doing helping to eliminate the Jewish-Bolshevik threat (Rosenberg I934: 356). The northern countries would serve as a racial barrier, preventing the spread of Jewish blood (internal) and as a spatial barrier halting the geographic spread of Bolshevism (external), thereby facilitating Nazi Germany's control of Europe. The 'Nordic idea' thus developed from a sociological-racial theory into an aggressive foreign policy.

One of the best-known practical manifestations of National Socialist racial policy in the Nordic countries, particularly in Norway, was the utopian enterprise 'Lebensborn'. This enterprise, which was established in 1935 by Heinrich Himmler to increase both the size and quality of the 'Aryan race', offered extensive support to women impregnated by German SS soldiers throughout the pregnancy, birth and early years of the child's upbringing. At first, institutions for care of these women and their children were established only in Germany. However, following the outbreak of the war, similar establishments were founded in other countries, including Austria, Poland, Denmark, France, Belgium, Holland, Luxembourg and Norway (the last had the most such institutions, second only to Germany), to care for the children of local women fathered by German SS soldiers serving in those countries. ${ }^{9}$

Another unique policy vis-à-vis the 'Nordic race' implemented in Norway was Heinrich Himmler's programme to settle Norwegian farmers in Eastern Europe. This was part of the endeavour to establish the rule of the northern European peoples over the Slavic peoples that would characterise the post-war new European order. Himmler began to take steps towards realising this programme as early as I 94I, when he invited a delegation of Norwegian farmers to train in Germany prior to their settlement in the Lublin district of Poland. However, to the great disappointment of the Germans, first and foremost among them Himmler, the reality did not accord with their expectations: not enough Norwegian farmers were prepared to relocate to Poland, and the Germans' programme to settle Norwegians in Eastern Europe was never realised (Emberland 2013: I I 9-2 I).

The Jews, part of the 'Semitic sub-race', and the Scandinavian peoples, belonging to the superior 'Nordic race', were located at two

9 For an in-depth examination of this subject see Ericsson and Simonsen 2005. 
opposite poles of German National Socialist racial theory. This polarity is evident also in the Germans' behaviour towards the general population of Norway, as part of the preferred Nordic race, and the treatment of the Jewish community in Norway, as members of the inferior Semitic race. While the steps that the Germans implemented vis-à-vis the Norwegian Jews (with the agreement of the Norwegian government) were intended to isolate the latter, physically and emotionally, from the rest of the Norwegian population, and consequently to weaken the Norwegians' feelings of brotherhood towards their Jewish co-citizens, the German attitude towards the local population, as many Norwegians felt and still feel to this day, was often characterised by restraint and fairness, in some cases even friendliness. Guided by the Nazi racial ideology, the Germans sought to draw closer to the general Norwegian population while at the same time to remove themselves from the country's Jews. An analysis of Nazi Germany's racial plans for the Norwegians compared to the inferior racial status and fate of the country's Jews can explain the events of the Second World War in Norway in a different light, both nationally and in a wider European context.

\section{Sweden: the policy behind the rescue}

The common image of Sweden during the Second World War, as a country engaged in rescue and rehabilitation efforts, is rooted first and foremost in its success in remaining neutral throughout the war years. Among the nation's best-known acts is the 'White Buses' operation, headed by Count Folke Bernadotte, which was organised by the Danish and Norwegian authorities and implemented by the Swedish Red Cross. In the framework of this operation, around 20,000 prisoners were liberated from various camps in Europe during April and May I 945, and were subsequently sent to Sweden for lengthy rehabilitation. Similarly famous are the activities of Raoul Wallenberg, a Swedish diplomat descended from a wealthy and established banking family, who produced thousands of 'protective passports' for Hungarian Jews in July I944 and made a decisive contribution to the management of the 'international ghetto' in Budapest. In so doing, Wallenberg saved, among others, tens of thousands of Jews from certain death. In Israel, as well as outside it, two other Swedish actions received widespread recognition: the opening of the country's borders to the Jews of Denmark as they fled deportation in the autumn of 1943, and the post-war rehabilitation of around Io,ooo Jews, former prisoners of German camps (the vast majority of whom were Jewish women from Poland), at the request of the UNRRA organisation.

The Second World War constituted a watershed in Swedish immigration policy. Yet, in contrast to the common perception that it was the arrival of the Danish Jews in October I 943 which led to the stark change in Swedish immigration policy, a view that took root among both professionals and the general public, Sweden actually absorbed a great number of refugees throughout the entire war, even before October 1943, and only a small percentage of them were Jews. In the autumn of 1942, Sweden accepted 30,000 refugees from Norway, around 800 of them Jewish; in the autumn of 1943 it accepted Iо,000 refugees from Denmark, of them around 7,200 Jews; from Finland approximately 80,000 refugees, largely children evacuated by their families; and around 25,000 refugees arrived from the Baltic states (mainly Estonia) in the autumn of I944. Among the refugees from Finland, Estonia, Lithuania and Latvia, there were no Jews (Byström and Frohnert 2013: 33-4). 


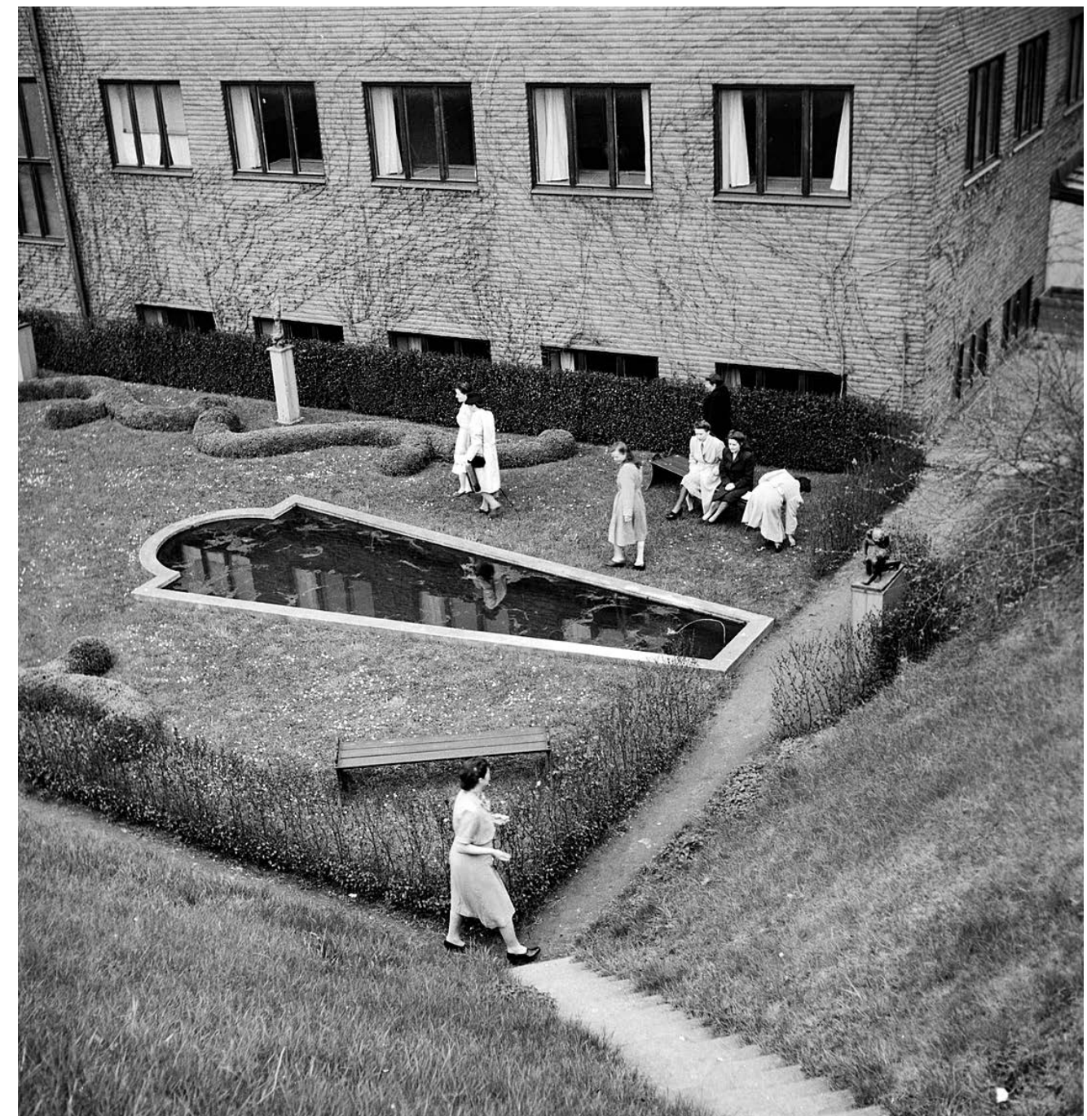

Former concentration camp prisoners who have recently arrived in Sweden on the 'White Buses'. K. W. Gullers, 1945. Nordiska museet (CC BY-NC-ND).

The relatively low number of Jews among the general refugee population in Sweden suggests that, during the second half of the war, Sweden viewed efforts to rehabilitate the Nordic brotherhood, which was critically damaged during the war as a result of the different fates suffered by the various Nordic countries, as no less important than distracting international public opinion from its collaboration with Nazi Germany. The latter aim was to be achieved by carrying out humanitarian actions (also towards persecuted Jews), ensuring Sweden a place alongside the Allies at the end of the war. ${ }^{10}$ However, in agreeing to open its gates to refugees from Norway, Denmark, Finland and the Baltic states, it seems that Sweden

10 Paul A. Levine, however, argued for a profound change of attitude in the Swedish administration towards Jewish refugees during the war. See the example of the under-secretary in Sweden's Foreign Office, Gösta Engzell, in Levine 2002. 
welcomed the Jews of these states as fleeing citizens of neighbouring Nordic countries, not because of their racial persecution. Might it be that they were rescued because of their Nordicness and not because of their Jewishness? Examining the fate of Scandinavian Jewry from this perspective will shed a different light on Sweden's rescue efforts. Likewise, it will enable us to draw more complex and general insights regarding the context in which not only the attempts at extermination but also the attempts to rescue the persecuted Jewish minority took place during the Second World War.

\section{Denmark: war compensation and the welfare state}

Over 99 per cent of Denmark's Jews (around 7,200 persons) were saved during the Second World War. Consequently, in the memory of the Holocaust that developed both in Israel and internationally, Denmark was depicted as a ray of light in an era of darkness (KerenCarmel 2019: 67). The Danish case has also been presented as exceptional in view of the treatment that the Jews received upon their return from the safe haven of Sweden at the end of the war and their rapid re-integration into society. Thus, for example, thirteen-yearold Emilie Roi described the extraordinary return to Denmark together with her family at the conclusion of the war, having spent eighteen months in Sweden:

We ourselves, like most Danish Jews, went back to Denmark. We found our house as we had left it. And - I must say it just one more time - in this, too, Denmark was special. Almost everywhere else in Europe, returning Jews found their homes had been broken into, and everything of value stolen. But our house was untouched: not a brick wrenched loose, not a window smashed. Only the garden had changed. Everything there had run wild. It looked like a jungle. The grass had grown almost to the height of a man, and all the paths had disappeared. (Roi I 990: 79)

Yet, a comparison of the Jews' return to Denmark with the reception that they received in other European countries reveals the exceptional nature of the Danish case from another perspective. The successful re-integration of Danish Jews after the war (a process comparable to that of members of the Communist underground who had fled the country), albeit not without difficulties, is often presented as a direct continuation of the local population's positive attitude towards them as they fled the country in October r 943. However, the reason for this was in fact different: it was a clear and focused policy implemented by the country's authorities.

In two recent, innovative articles, the Swedish historian Mikael Byström (2014) and the Danish historian Sofie Lene Bak (2016) have drawn a fascinating connection between the policy of absorbing refugees (with an emphasis on Jewish refugees) pursued by Sweden and Denmark at the end of the war and the entrenchment of the socialist principle regarding the state's responsibility for the welfare of all its citizens. In the case of Denmark, Bak demonstrated that the Ministry for Welfare Services, which was established in I943, paid the rent, including associated expenses, for 97 apartments and stored the contents of another 350 homes while the Jewish owners were in Sweden. In this way, the ministry succeeded in protecting the possessions of the state's Jews from plunder by Germans and Danes alike (Bak 2016: I 37). Later, Bak continues, in order to guard the property the Danish authorities applied the 'Law of Compensation to the Victims of the Occupation', which was based on the principles of the I 934 'Law on 
Invalidity Pension to Causalities in Conscript Forces' and on two additional laws benefiting injured parties that were passed in Denmark shortly after the German occupation in April r 940. The authorities sought, first and foremost, to achieve the optimal integration of war victims among the local population and reduce disagreements between them; as such, it was vital to ensure that these two groups had equal rights. In this sense, the Jews who returned to Denmark after the war, and who constituted the largest group of those receiving help from the state because of damage sustained in the war half of them, around 4,200 people, received financial help from the authorities upon their return - constituted a significant step in the development of the Danish welfare state in the r940s (ibid., p. I38). The extensive help afforded to the refugees was the result of a comprehensive welfare policy implemented by the authorities, which over the years became an essential part of what is known today as the 'Nordic model'. Denmark thus behaved in an exceptional manner not only when it saved most of its Jewish population in October 1943 but also after the war, when it endeavoured to re-integrate them into society comprehensively by implementing and developing principles such as the extensive and universal social rights upon which the Nordic welfare state is based.

\section{Commemoration in Israel}

Even more than the similarities, the three examples above from Norway, Sweden and Denmark reveal that the events of the Second World War in general, and the Holocaust in particular, took a different course in each of the three Scandinavian countries. The distinct conduct of each state during the war is a corollary of the unique starting point in each country, the national context that influenced the development of events, the fate of the general population on the one hand and that of the Jewish community on the other, and the varied responses of the authorities to the German threat.

Yet, despite the many differences between them in regard to the attitudes towards their Jewish communities, these three countries merged into one bloc in the Israeli commemoration of the Holocaust that materialised from the I95os onwards. The positive depiction of these states, in the Danish case verging on mythological, pushed aside the less complimentary aspects of their wartime conduct, on both the government level and among the general population in Israel. Indeed, all three were portrayed as staunch opponents of Nazi German policy, fighting stubbornly for the Jews living in their midst and battling against the occupier through fearless underground movements. One possible explanation for this may be the Nordic states' attempts to draw closer to each other after the war. Among the results of these efforts were the establishment of the Nordic Council,11 which sought to strengthen official cooperation between these member nations, and the rotation that they agreed upon after the war vis-à-vis holding positions in the UN.

Although, as was noted above, the events of the Holocaust in Scandinavia had been commemorated since the r940s, it was anchored in statehood by the Eichmann trial, which began on i I April r96r. Gideon Hausner, the lead prosecutor, clearly espoused there the positive representation of Scandinavian behaviour towards the Jews during the war:

11 The founding nations of the Nordic Council, which was established in 1952 , were Denmark, Iceland, Norway and Sweden. Finland joined later (I 955), as did the Faroe Islands and Åland Islands (1 970) and Greenland (1984). 
In the terrible, black night that fell on Europe after Hitler rose to power, there are also sparkling lights, and the Jewish people will not forget those who treated it well, just as it will not forget its persecutors. We will not forget the nobility of the Danish nation ... We will remember the Norwegian underground that, at great risk to their own lives, smuggled Jews to Sweden. We will remember the Swedes for their grace. (Hausner 20 I I : 388-9, my translation)

The three Scandinavian countries are presented at once as exceptional and as one bloc: the Danish and Swedish peoples were depicted in a sweeping fashion as a collective, the Norwegian underground as a one-dimensional body. In contrast, later in the speech, Hausner described saviours of Jews from other countries as individuals, a minority among the general population, mentioning, for example, 'the saviours of the Jews' in Greece, Yugoslavia and Poland. During the trial two witnesses, out of a total of around a hundred, testified regarding the wartime events in Denmark and Norway. In session 35, Werner David Melchior, the son of the chief rabbi of Denmark, described the heroic manner in which the local population, led by the king, rallied to support the Jews, explaining that this prevented the extermination of the Jews and enabled their escape to neutral Sweden. In the following session, no. 36, Henriette Samuel, the wife of Isaak Samuel, the chief rabbi of Norway who disappeared in the winter of 1942 , described how the Norwegian underground helped to save her life and the lives of their children. These two witnesses focused on the

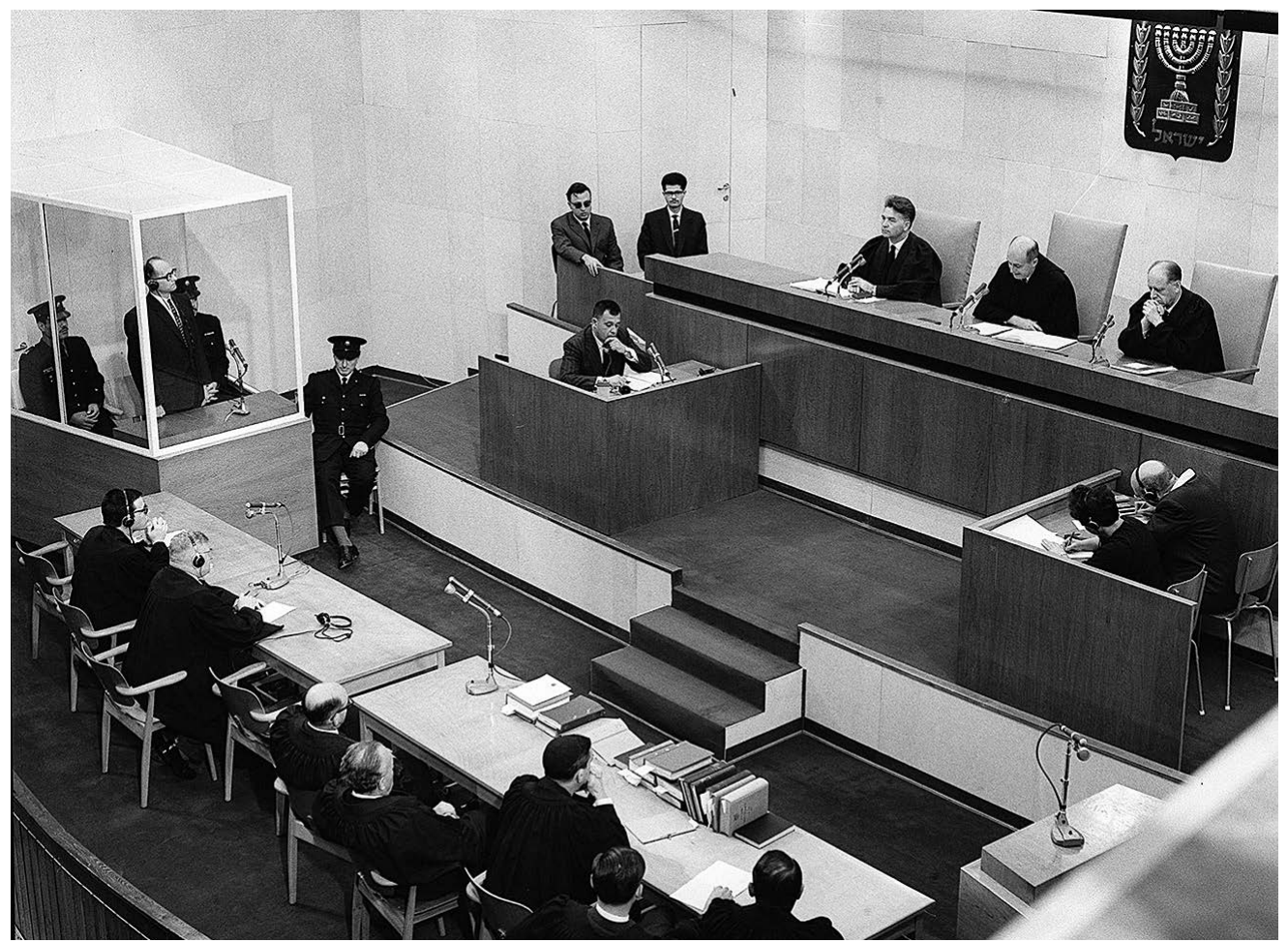

Defendant Adolf Eichmann (inside glass booth) is sentenced to death by the court at the conclusion of the Eichmann Trial. The defence counsel, Robert Servatius, is seated on the right (with white hair and headphones) at the table on the left with two people sitting at it. Israeli Government Press Office, 15.12.1961, Wikimedia Commons. 
rescue actions that the Danish people and the Norwegian underground carried out, while the collaboration of some citizens and certain bodies with Nazi Germany were almost completely overlooked. Furthermore, these two testimonies prominently highlighted the status of Sweden in the war as a safe haven for the fleeing Scandinavian Jews.

A short time after the Eichmann trial, the committee for the selection of Righteous among the Nations was established in Yad Vashem. This was partially due to increased public pressure, following the trial, to recognise the saviours and not merely to condemn the persecutors. A significant number of rescuers from Scandinavia were among the first to be honoured by Yad Vashem: in recognition of the actions of the Danish underground, the Danish people and King Christian X, three trees were planted on ro October I963; the Swedish diplomat Raoul Wallenberg was honoured as a Righteous among the Nations on 26 November 1963; Georg Ferdinand Duckwitz, the German diplomat who leaked the date on which Denmark's Jews were to be deported, was recognised on $2 \mathrm{I}$ March I97I (to this day, he remains the only German diplomat to receive this honour); and a further tree was planted for the Norwegian underground on 20 March I 978.12

In some cases, Yad Vashem's recognition of individuals and bodies was preceded by complex debates. In the case of the Danish underground, for example, Yad Vashem initially planned to honour individual members who were explicitly involved in hiding Jews and smuggling them to Sweden.

12 It should be noted that in contrast to individuals, collectives were only recognised by the planting of a tree, since according to the regulations of Yad Vashem only individual persons can be granted the honorific status of Righteous among the Nations.
However, the leadership of the former underground asked the institution to avoid recognising individuals and instead honour the entire Danish underground. Yad Vashem granted the request because in fact it served both parties: for Denmark, identifying all members of the underground as opposing the discrimination against the country's Jews supported the image of this body as battling against the Nazi occupier and its plans in an all-encompassing manner, an image that reflected on the Danish nation as a whole (Følner 20II: 223-3I), while for Israel the unique case of Denmark - the

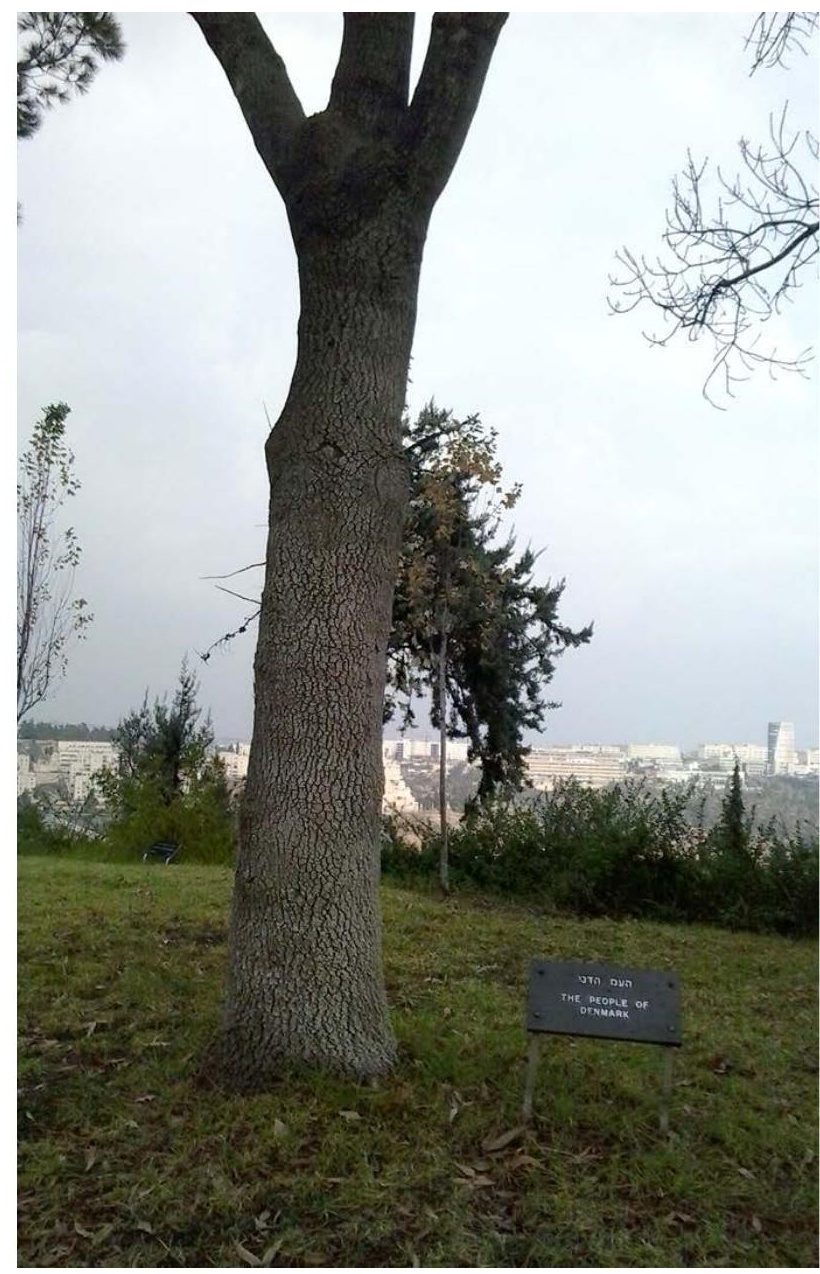

A tree in Yad Vashem (Jerusalem) planted in 1963 in honour of the people in Denmark. Wikimedia Commons. 
entire underground, the entire nation and the king at its head acting on behalf of the persecuted Jews - highlighted this country as an exception that proved the rule.

The recognition of the German diplomat Georg Ferdinand Duckwitz as one of the Righteous among the Nations was also a product of extraordinary circumstances: in his case, the request for the honour originated from the Israeli Ministry for Foreign Affairs, together with Israel's embassy in Bonn, Germany, and not from the Jews saved by his actions, as is usually the case. ${ }^{13}$ This testifies to the importance that the ministry attributed at the time to any steps that could improve relations with West Germany, then under the leadership of Willy Brandt (who served as chancellor from r 969 to I974).

The process of recognising the Norwegian underground was the longest and most complicated of all. It was accompanied by intense disagreements over whether all the members of the Norwegian underground (or at least a majority of them) were involved in saving the country's Jews or whether this was restricted to a limited number of members, while the rest engaged in activities that at best had no connection to the Jews and at worst opposed their needs and interests. The debate also touched upon the appropriate weight that should be accorded to political considerations in this decision, as is evident from the protocol of the preceding discussions: 'It seems to me that the intention of the legislator was clear he had in mind an individual who endangered himself in order to save even one soul. I see granting this title to an entire organisation as a political act'. ${ }^{14}$ In 1978 , a decision was

13 Chava Bitan to Avner Idan (Israel's delegate to Bonn), 26 March I 970, Israeli State Archives.

14 Protocol of the session held on I 9 April I979, p. I I. Quoted in Gur Arie 2007: 63. finally reached, and a tree was planted in Yad Vashem in recognition of the Norwegian underground. Yet, while in Hebrew the words on the sign next to the tree say 'The Norwegian Underground', the wording in English is slightly different: 'Members of the Underground who Helped Jews'.

\section{The Holocaust and Israeli foreign policy}

Since the r 96os, the granting of the honorific Righteous among the Nations and planting of trees in the Avenue of the Righteous in Yad Vashem were, among other things, motivated by the understanding that such acts could improve Israel's relations with European nations, mainly those in the western part of the continent. 15 Prime minister Ben Gurion was concerned about the negative image that these countries, in particular West Germany, had acquired following the Eichmann trial, and therefore attempted to balance it by commemorating the actions of individual citizens. However, the recognition also had a more practical political goal: honouring the Righteous among the Nations not only buttressed international recognition of the State of Israel but also strengthened relations with those countries in which the Righteous lived. Thus, Gideon Hausner described the situation in retrospect:

At the time, Ben Gurion was seeking ways to bolster Israel's international status, and he anticipated from the outset the rising power of the Germans in the global arena. He fervently and determinedly claimed that Germany is no longer Nazi, that it has changed, that it is permissible to develop

15 For a recent example, see Sarah Gensburger, National Policy, Global Memory: The Commemoration of the 'Righteous' from Jerusalem to Paris, 1942-2007 (New York: Berghahn, 2016). 


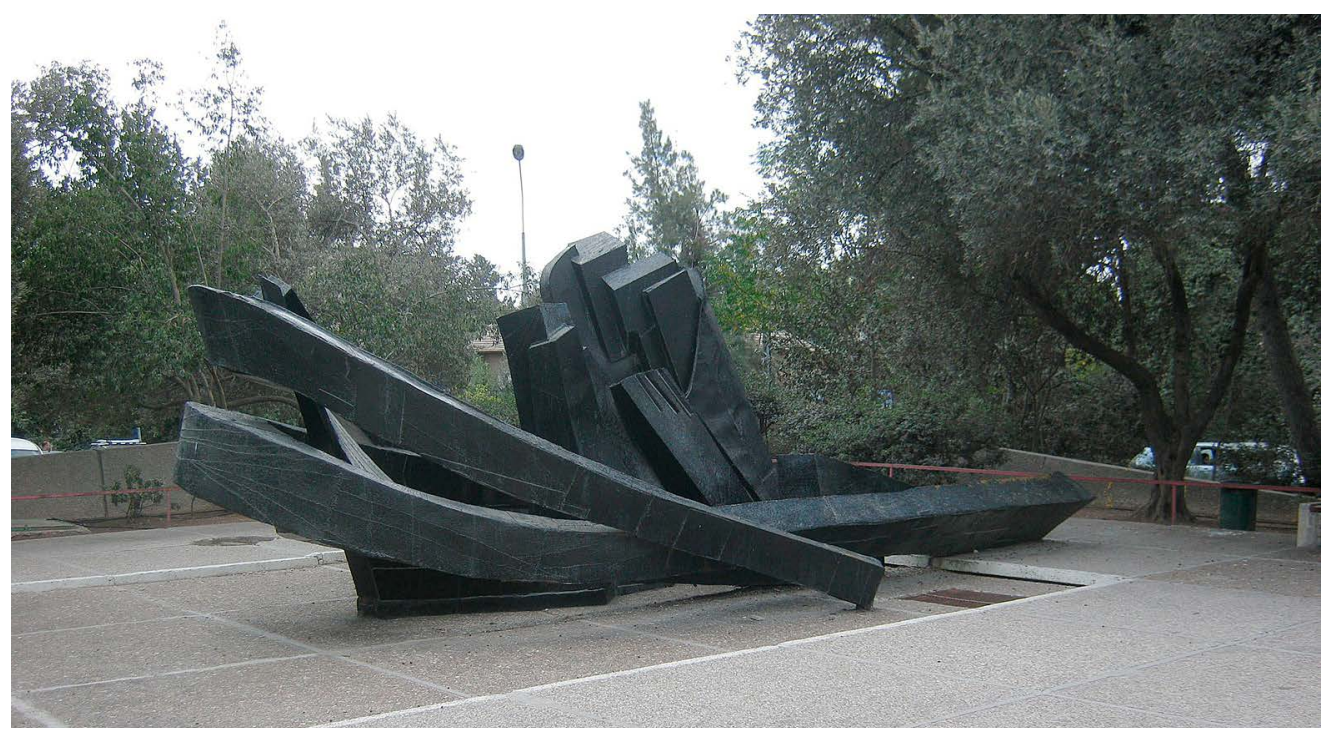

Denmark Square Memorial by Roda Reilinger at Beit Hakerem, Jerusalem. Photo taken in September 2013 by YoavR. Wikimedia Commons (CC BY-SA 3.0).

that improved the relations between Israel and the Scandinavian states but rather the opposite: the positive representation of the Scandinavian countries in the framework of the Eichmann trial was a result of the close relations already existing between Israel and the three Scandinavian states.

This claim is further reinforced by comparison with the case of another Nordic country, Finland. During the Second World War, Finland joined Nazi Germany, fighting together against the Soviet Union on the Eastern Front. As part of the Axis, and Germany's ally, Finland was also required to take steps to solve the 'Jewish problem' within its borders. ${ }^{16}$ As with the stance adopted by King Christian X of Denmark and other senior officials in the Danish government, during a meeting in August 1942, the Finnish prime minister, Johan Wilhelm (Jukka) Rangell, informed Heinrich Himmler that no such

16 The following information was retrieved from Yad Vashem's Virtual Lexicon, s.v. 'Finland'. problem existed in Finland. Himmler, wanting to avoid aggravating the Finns, whose help on the Eastern Front was vital, refrained from revisiting the topic. Not only were the Jews of Finland saved from deportation and murder, but throughout the war Finland continued to conscript Jewish soldiers and officers into its army, many of them fighting alongside German officers and soldiers in joint units. All members of Finland's civil Jewish community survived the Second World War, apart from eight Jews who were handed over to Nazi Germany and all of whom, apart from one, met their death there. In I971, a group of volunteers from Finland established in their memory the agricultural settlement Yad Hashmona in the Judean hills, near Jerusalem.

The conduct of Finland and Denmark during the Second World War is characterised by significant differences, yet there are also clear similarities between the fates of the Jews in these two countries. In both cases the national leadership refused to discriminate against the country's Jewish 
citizens or assist in the negation of their rights or their deportation, and the German reaction demonstrates that the Nazis preferred continued fruitful cooperation to the destruction of the (few) Jews in their borders. Why, therefore, in Israeli Holocaust commemoration was the Danish nation honoured for its behaviour during the Holocaust, while the efforts of Finland on behalf of its Jews sank like a stone to the depths of the sea? Why were three trees planted in honour of the Danish king, the Danish underground and the Danish people, in addition to recognising a further twenty-two Danish individual citizens as Righteous among the Nations, while in Finland not one body and not even one individual was awarded this distinction? The answer lies in the relations between Finland and the State of Israel in the r 950 os. In contrast to Sweden, Denmark and Norway, with which strong professional and official ties were woven at this time, no close relations developed between Finland and Israel. Finland's (complex) decision in I948, in the first stages of the Cold War, to sign the 'Agreement of Friendship, Cooperation and Mutual Assistance' with the Soviet Union led these countries to draw closer, while at the same time driving a wedge between Finland and the Scandinavian countries as well as other Western nations, including Israel. The international conflict between Israel and the Soviet Union, which intensified in those years, also led to loose relations between Finland and Israel. Consequently, the Ministry of Foreign Affairs and senior Israeli leaders saw no reason to invest resources in glorifying Finland's actions during the Holocaust in order to strengthen relations with that nation.

\section{Conclusion}

The policy adopted by the Scandinavian countries at the break of the Cold War, as a unified bloc, accorded perfectly with the image of Demark, Norway and Sweden that emerged in Israel's Holocaust memorial culture during the r95os. The exceptional rescue of Denmark's Jews, the help of the Norwegian underground in smuggling Jews out of their country, as well as the actions of Raoul Wallenberg and Sweden's comprehensive rehabilitation efforts after the war, not only led to the depiction of the three Scandinavian countries' conduct during the war as unified in one bloc, but also glorified their actions and accorded them the high moral status of rescuers and rehabilitators. The events of the Second World War augmented the consolidating image of the Scandinavian countries as humanitarian nations that prioritise minority and human rights, rendering them 'a ray of light in the darkness'. A thread was woven connecting the representation of the events of the Holocaust in Scandinavia with the nations' image as 'moral superpowers'.

From the perspective of the State of Israel, the close relations that developed at the end of the r 940s with Sweden, Denmark and Norway, both among political echelons and on professional levels, led the senior governmental leadership to commemorate the positive aspects of the Scandinavian states' conduct during the Holocaust and to avoid mentioning the less complimentary aspects. The Eichmann trial, which was held in I961, and following it the honour that the Scandinavian states were awarded by Yad Vashem - by planting trees to recognise the activities of their organisations and honouring individuals as Righteous among the Nations - provided an official stamp for Israel's close ties with these states, which 
had already been in place for over a decade. Thus, it was not the trial that moulded the positive image of the Scandinavian states in Israeli commemorative culture but rather the opposite: the trial further anchored an already well-entrenched image of a bloc of states that in fact behaved singularly towards their Jews during the Holocaust, which developed as a corollary of the close links between the countries. The chronological proximity of the Holocaust and the establishment of the State of Israel, two momentous events in Jewish history, had significant ramifications for both the commemoration of the Holocaust in the nascent state and its foreign policy, mainly, but not only, during the first decade of its existence.

The historian Orna Keren-Carmel received her MA in European Studies from Aarhus University (Denmark) and her doctorate, with her thesis entitled 'The Rescue of Danish Jewry in Israeli Historiography and Culture of Memory (1943-2013)', from Tel

Aviv University (Israel).

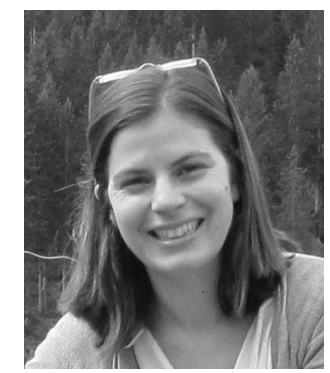

Her research interests are the 'Nordic model', Scandinavian welfare in the twentieth century, the Second World War and its memory in the Scandinavian countries and Israeli-Scandinavian relations through the years. Since 2018 she has been teaching and researching in the European Forum at the Hebrew University of Jerusalem. Currently she is writing a book on the beginning of Israeli-Scandinavian relations (to be published in 2021).

\section{References}

\section{Archive sources}

Israeli State Archives, Jerusalem 4464/I4-TZ. Chava Bitan to Avner Idan (Israel's delegate to Bonn), 26 March I970.

Yad Vashem Archive, Jerusalem

AM/r, file 94, Mordechai Shenhavi to Benjamin Slor, I7 June I947.

\section{Literature}

Adams, Jonathan, and Cordelia Heß (eds.). 2020. Antisemitism in the North: History and State of Research (Berlin and Boston: De Gruyter).

Bak, Sofie Lene. 20 I6. 'Repatriation and restitution of Holocaust victims in post-war Denmark', in Jewish Studies in the Nordic Countries Today, eds. Ruth Illman and Björn Dahla, Scripta Instituti Donneriani Aboensis, 27 (Åbo/Turku: The Donner Institute), I 34-52.

Byström, Mikael. 20 1 3. 'The last bastion of Swedish refugee policy: The National Refugee Board, I 94 I-50', in Reaching a State of Hope: Refugees, Immigrants and the Swedish Welfare State, 1930-2000, eds. Mikael Byström and Pär Frohnert (Lund: Nordic Academic Press), I I 6-30.

-20I4. 'When the state stepped into the arena: the Swedish welfare state, refugees and immigrants I 930s-50s', Journal of Contemporary History, 49(3): 599-62 I.

Byström, Mikael, and Pär Frohnert. 2013. 'Introduction I', in Reaching a State of Hope: Refugees, Immigrants and the Swedish Welfare State, 1930-2000, eds. Mikael Byström and Pär Frohnert (Lund: Nordic Academic Press), 29-38.

Corell, Synne. 2010. Krigens ettertid. Okkupasjonsbistorien i norske historiebøker (Oslo: Scandinavian Academic Press).

Emberland, Terje. 2013. 'Pure-blooded Vikings and peasants: Norwegians in the racial ideology of the SS', in Racial Science in Hitler's New Europe, 1938-1945, eds. Anton Weiss-Wendt and Rory Yeomans (Lincoln: University of Nebraska Press), Io8-28.

Ericsson, Kjersti, and Eva Simonsen (eds.). 2005. Children of World War II: The Hidden Enemy Legacy (Oxford: Berg Publishers).

Følner, Bjarke. 20 I r. 'Afterword', in Sofie Lene Bak, Nothing to Speak of: Wartime Experiences of the Danish Jews 1943-1945 (Copenhagen: The Danish Jewish Museum).

Gensburger, Sarah. 201 6. National Policy, Global Memory: The Commemoration of the 'Righteous' from Jerusalem to Paris, 1942-2007 (New York: Berghahn).

Gur Arie, Hemda. 2007. 'Hakarat ha-ne'elam: Ha-Shoah ba-mishpat ha-Yisre'eli', PhD dissertation (unpublished), Tel Aviv University.

Hatsofe. I 962. 'Rosh memshelet Shvediya mekave lehiduk-yeter im medinat Israel', Hatsofe, 27-3.1962: I. 
Hausner, Gideon. 20 I I. Eichmann Trial in Jerusalem (Tel Aviv: Hakibbutz Hameuchad) [in Hebrew].

Henriksen Waage, Hilde. 2000. 'How Norway became one of Israel's best friends', Journal of Peace Research, 37(2): I 89-2 I I.

Herut. r 957. 'Besha'arei herut, Israel ve'evelah shel Norvegiya', Herut, 22.9.I 957: I.

Holmila, Antero, and Karin Kvist Geverts. 20 I I. 'On forgetting and rediscovering the Holocaust in Scandinavia: introduction to the special issue on histories and memories of the Holocaust in Scandinavia', Scandinavian Journal of History, 36: 520-35.

Jensen, Mette Bastholm, and Steven B. Jensen (eds.). 2003. Denmark and the Holocaust (Copenhagen: Institute for International Studies, Department for Holocaust and Genocide Studies).

Kabalek, Kobi. 20 I r. 'The commemoration before the commemoration: Yad Vashem and the Righteous Among the Nations, I945-1963', Yad Vashem Studies, 39(I): I 4 I-70 [in Hebrew].

Keren-Carmel, Orna. 2019. 'The grey truth: the rescue of Danish Jewry during the Holocaust in Israeli culture of memory', Zmanim: A Historical Quarterly, I41: 64-75 [in Hebrew].

Kirchhoff, Hans (ed.). 2002. Nyt lys over oktober 1943 (Odense: Syddansk Universitetsforlag).

Koblik, Steven. 1988. The Stones Cry Out: Sweden's Response to the Persecution of the Jerws, 19331945 (New York: United States Holocaust).

Kreth, Rasmus, and Michael Mogensen. 1995. Flugten til Sverige. Aktionen mod de danske jøder oktober 1943 (Copenhagen: Gyldendal).

Levine, Paul A. 1 996. From Indifference to Activism: Swedish Diplomacy and the Holocaust, 1938-1944 (Uppsala: Uppsala University).

-2002. 'Attitudes and action: comparing the responses of mid-level bureaucrats to the Holocaust', in Bystanders to the Holocaust: A Re-evaluation, eds. David Cesarani and Paul A. Levine (London: Frank Cass Publishers), 2 I $2-36$.

Mendelsohn, Oscar. 1969-86. Jødenes historie i Norge gjennom 300 ar (Oslo: Universitetsforlag).

Roi, Emilie. I 990. A Different Story (Jerusalem: Yad Vashem).

Rosenberg, Alfred. 1934. Der Mythus des 20. Jabrbunderts (München: Hoheneichen Verlag).
Sode-Madsen, Hans (ed.). I 993. Foreren har befalet! Jødeaktionen oktober 1943 (København: Samleren).

Yad Vashem Virtual Lexicon. 2020. 'Finland', in Yad Vashem Virtual Lexicon [yadvashem. org], <https://www.yadvashem.org/odot_pdf/ Microsoft $\% 20$ Word\%20-\%205852.pdf $>$ (accessed 7.10.2020). 